\title{
FAKTOR-FAKTOR YANG BERHUBUNGAN DENGAN KEJADIAN KECELAKAAN KERJA DI
} PABRIK GULA BONE ARASOE

\author{
Ria Astuti ${ }^{1}$ dan Zaenab ${ }^{2}$ \\ 1,2, Jurusan Kesehatan Lingkungan Poltekkes Kemenkes Makassar \\ *riaastuti.amir03@gmail.com
}

\begin{abstract}
The cause of the accident is generally due to unsafe conditions and unsafe acts of workers. Specifically regarding the unsafe action (unsafe acts) is very closely related to the human factor or happen because of human error. The purpose of this research is to know the factors related to the incidence of work accidents in Bone Arasoe sugar factory. Data collection by way of observation by using a questionnaire. This type of research is research observational analytic with cross sectional approach and use statistical test chi square, with a total population of 144 employees and the number of samples as much as 106 employees elected by simple random sampling. The results showed that there is a relationship of factor health checks with the incidence of work accidents $(p=0.002<0.05)$ work accident with knowledge $(p=0,032<0.05)$ use of protective tools themselves with work accident $(p=0.023<0.005)$, and there is no visible relationship or no relationship with training accident factors work $(p=0.055>0.05)$ as well as the results showed there were 74 people $(70 \%)$ respondents who have experienced workplace accident. As for the conclusion of the research is there a significant relationship between the medical examination, the knowledge and the use of Protective $D$ with the Genesis accident. There is no relationship between the incidence of training by accident. Therefore, it is recommended that surveillance be done against employees before doing the activity or enter in the production area.
\end{abstract}

Keyword : accidents, Protective Tools Themselves, the sugar factory

\section{ABSTRAK}

Penyebab kecelakaan kerja secara umum adalah karena adanya kondisi yang tidak aman dan tindakan tidak aman dari pekerja. Khusus mengenai unsafe action (tindakan tidak aman) ini sangat erat kaitannya dengan faktor manusia atau terjadi karna kesalahan manusia. Tujuan penelitian ini untuk mengetahui faktor-faktor yang berhubungan dengan kejadian kecelakaan kerja di Pabrik Gula Bone Arasoe. Pengumpulan data dengan cara observasi dengan menggunakan kuesioner. Jenis penelitian yang digunakan adalah penelitian observasi analitik dengan pendekatan cross sectional dan menggunakan uji statistik chi square, dengan jumlah populasi sebanyak 144 karyawan dan jumlah sampel sebanyak 106 karyawan yang dipilih secara simple random sampling. Hasil penelitian menunjukkan bahwa ada hubungan faktor pemeriksaan kesehatan dengan kejadian kecelakaan kerja $(p=0,002<0,05)$ pengetahuan dengan kejadian kecelakaan kerja $(p=0,032<0,05)$ penggunaan alat pelindung diri dengan kejadian kecelakaan kerja $(p=0,023<0,005)$, serta tidak terlihat ada hubungan atau tidak ada hubungan faktor pelatihan dengan kejadian kecelakaan kerja $(p=0,055>0,05)$ serta hasil penelitian menunjukkan terdapat 74 orang $(70 \%)$ responden yang pernah mengalami kejadian kecelakaan kerja. Adapun kesimpulan penelitian ini adalah terdapat hubungan yang signifikan antara pemeriksaan kesehatan, pengetahuan dan penggunaan APD dengan kejadian kecelakaan kerja. Tidak terdapat hubungan antara pelatihan dengan kejadian kecelakaan kerja. Oleh karena itu, disarankan agar dilakukan pengawasan terhadap karyawan sebelum melakukan kegiatan atau masuk dalam area produksi.

Kata Kunci : Kecelakaan kerja, Alat pelindung diri, Pabrik gula

\section{PENDAHULUAN}

Penggunaan teknologi yang maju sangat diperlukan untuk memenuhi kebutuhan hidup manusia secara luas, namun tanpa disertai dengan pengendalian yang tepat akan dapat terjadinya kecelakaan, terutama pada era industrialisasi yang ditandai adanya proses mekanisasi, elektrifikasi, dan modernisasi. Dalam keadaan demikian penggunaan mesin, instalasi, dan bahan-bahan berbahaya akan terus meningkat sesuai kebutuhan industrialisasi. Hal tersebut memberikan kemudahan bagi suatu proses produksi. Efek samping yang tidak dapat dihindari adalah bertambahnya jumlah dan ragam sumber bahaya bagi pengguna teknologi dan faktor lingkungan kerja yang tidak memenuhi syarat Keselamatan dan Kesehatan Kerja (K3) (Ismi dkk, 2015).

Keselamatan dan Kesehatan Kerja (K3) adalah segala bentuk kegiatan untuk menjamin dan melindungi keselamatan dan kesehatan tenaga kerja melalui upaya pencegahan kecelakaan kerja dan penyakit akibat kerja.
Keselamatan kerja tercermin pada keadaan di tempat kerja yang meliputi keadaan tidak aman, tindakan tidak aman maupun keadaan lingkungan kerja. Berdasarkan piramida perbandingan kecelakaan disebutkan bahwa keadaan dan tindakan tidak aman merupakan dasar dari kejadian hampir celaka maupun kecelakaan (Fitria dkk, 2014).

Kecelakaan kerja adalah suatu kejadian yang tidak dikehendaki dan tidak diduga semula dapat menimbulkan korban manusia dan atau harta benda (PERMENAKER No.03/MEN/1998). Menurut Meiater kecelakaan kerja yaitu suatu kejadian yang tak terduga atau tiba-tiba dan dapat mengakibatkan gangguan pada suatu sistem dan individual yang mempengaruhi kesempurnaan penyelesaian tujuan sistem (Suwardi dkk, 2018).

Penyebab kecelakaan kerja secara umum adalah karena adanya kondisi yang tidak aman dan tindakan tidak aman dari pekerja. Khusus mengenai unsafe action (tindakan tidak aman) ini sangat erat kaitannya dengan faktor 
manusia atau terjadi karena kesalahan manusia. Kecelakaan kerja dapat disebabkan oleh dua hal yaitu, unsafe action dan unsafe condition. Unsafe action (tindakan tidak aman) sangat erat kaitannya dengan faktor manusia berupa budaya K3 atau merupakan semua tindakan yang dilakukan seseorang dimana tindakan tersebut dapat membahayakan diri sendiri, orang lain, peralatan maupun lingkungan yang ada disekitarnya. Sedangkan unsafe condition (kondisi tidak aman) merupakan penyimpangan dari standar yang dipatuhi untuk menghindari terjadinya kecelakaan ditempat kerja (Luthfil dkk, 2016).

Data International Labour Organization (ILO) tahun 2013, 1 pekerja di dunia meninggal setiap 15 detik karena kecelakaan kerja dan 160 pekerja mengalami sakit akibat kerja. Tahun sebelumnya (2012) ILO mencatat angka kematian dikarenakan kecelakaan dan penyakit akibat kerja (PAK) sebanyak 2 juta kasus setiap tahun (ILO, 2014).Tahun 2016 Dinas Tenaga Kerja Kota Makassar menargetkan 65\% dari 4.121 perusahaan menerapkan standar Kesehatan dan Keselamatan Kerja (K3). Dimana dari 4.121 perusahaan tersebut Dinas Tenaga Kerja berhasil mencapai target $64,74 \%$ perusahaan yang menerapkan standar kesehatan dan keselamatan kerja (K3) sebanyak 2.668 perusahaan dengan presentase capaian sebesar 99,60\%. Jumlah kecelakaan kerja pada tahun 2016 telah berhasil melampaui target penurunan yang direalisasikan sebesar 8,57\% dari target sebesar $5 \%$ dengan presentase capaian sebesar 171,43\%. Dari jumlah kecelakaan kerja pada tahun 2015 sebanyak 35 kasus mengalami penurunan pada tahun 2016 menjadi 32 kasus (Disnaker, 2018).

Pabrik Gula Bone Arasoe merupakan industri gula kristal putih yang berlokasi di Desa Arasoe Kecamatan Cina Kabupaten Bone. Pabrik Gula Bone Arasoe memiliki karyawan 144 yang tersebar dari bagian kantor sampai dengan bagian produksi. Dalam menjalankan proses oprasionalnya, bagian produksi dan instalasi berhadapan langsung dengan berbagai mesin mekanik. Berdasarkan tahap proses produksi yang ada di Pabrik Gula Bone Arasoe, prosesproses tersebut di bantu dengan peralatanperalatan yang modern, dan berpotensi beresiko bagi keselamatan dan kesehatan pekerja.

Kecelakaan kerja di khawatirkan mempengaruhi produktivitas kerja karyawan. Salah satu hal yang dapat mempengaruhi produktivitas kerja karyawan adalah lingkungan tempat karyawan bekerja dan jaminan terhadap risiko keselamatan dan kesehatan kerja, oleh karena itu perusahaan perlu melakukan peninjauan ulang kembali mengenai pelaksanaan SMK3 (Rini dkk, 2010). Hasil penelitian Sulhinayatillah (2017) di PT. PP London Sumatra Indonesia Tbk Palangisang Crumb Rubber Factory mengenai kecelakaan kerja, di dapatkan hasil bahwa terdapat hubungan yang signifikan antara penggunaan APD, perilaku karyawan, tingkat kerugian, masa kerja, lingkungan kimia dengan kecelakaan kerja. Oleh karena itu pihak industri disarankan sebaiknya melakukan pengawasan terhadap karyawan sebelum melakukan kegiatan atau masuk dalam area produksi.

Berdasarkan hasil penelitian yang dilakukan oleh A Syamsinar pada tahun (2013) di PT Perkebunan Nusantara Pabrik Gula Bone bagian Unit produksi menunjukkan bahwa, terdapat hubungan cara pemakaian dengan penggunaan APD, banyak yang memakai namun tidak memenuhi syarat, dan terdapat hubungan ketersediaan dengan pemakaian APD. Hal ini perusahaan belum menyediakan APD secara lengkap.

Bagian proses produksi di Pabrik Gula Bone Arasoe beresiko tinggi adanya kecelakaan kerja. Hal ini dikarenakan banyaknya jumlah tenaga kerja dan penggunaan mesin mekanik yang terdapat di bagian proses produksi. Maka hal tersebut perlu diperhatikan mengenai Keselamatan dan Kesehatan Kerja (K3).

\section{METODE \\ Desain}

bebas dalam penelitian ini adalah pelatihan,pemeriksaankesehatan,

pengetahuan,Alat Pelindung Diri (APD). Variabel terikat, yang menjadi variabel terikat dalam penelitian ini adalah kejadian kecelakaan kerja. Variabel pengganggu, yang menjadi variabel pengganggu dalam penelitian ini adalah masa kerja,umur,lingkungan kerja (fisik,kimia, biologis, psikologis).

\section{Tempat dan waktu}

Penelitian ini dilakukan di Pabrik Gula Bone Arasoe Desa Arasoe Kecamatan Cina Kabupaten Bone. Adapun pelaksanaan penelitian dilaksanakan yaitu sebagai berikut : Tahap persiapan dilaksanakan pada bulan Desember 2018- januari 2019 yaitu observasi awal, pengumpulan data dan seminar proposal.Tahap pelaksanaan penelitian dilaksanakan pada bulan maret-juni 2019 yang meliputi : pengumpulan data kemudian pengolahan data. 


\section{Jumlah dan cara pe ngambilan subjek Populasi}

Populasi dalam penelitian ini adalah seluruh karyawan atau pekerja yang bekerja ditempat yang beresiko terjadinya kecelakaan di Pabrik Gula Bone Arasoe, yaitu bagian instalasi dan pengolahan yang berjumalah 144 karyawan

\section{Subjek}

Subjek dalam penelitian ini diambil secara simple random sampling yang dijadikan sebagai subjek penelitian dengan sampel sebanyak 106 karyawan.

\section{Jenis dan Cara Pengumpulan Data Data primer}

Pengambilan data diperoleh melalui observasi langsung, wawancara pada responden dengan menggunakan kuesioner terhadap 106 orang pekerja Pabrik Gula Bone Arasoe

\section{Data Sekunder}

Data sekunder adalah data yang ada hubungannya dengan judul penelitian yang diperoleh langsung dari Pabrik Gula Bone Arasoe, jurnal, KTI sebelumnya, internet, dan buku-buku

\section{Pengolahan dan Analisa Data}

Pengolahan data dilakukan dalam menggunakan komputer dan alat hitung. Selanjutnya data disajikan dalam bentuk tabel distribusi frekuensi dan tabel analitik. Kemudian di Analisa dengan menggunakan Uji statistik Chi Square, dimana Taraf signifikan $a=0,05$ dengan ketentuan sebagai berikut :

Interpretasi :

Jika $p$, value $<0,05$ berarti hipotesis diterima ( $p$, value $<\alpha$ ) uji statistik menunjukkan adanya hubungan

Jika $p$, value $>0,05$ berarti hipotesis ditolak $(p$, value $>\alpha$ ) uji statistik menunjukkan tidak ada hubungan

\section{HASIL}

Kegiatan penelitian dilaksanakan sejak April - Mei 2019 bertempat di Pabrik Gula Bone Arasoe. Pengambilan data melalui kuesioner dan observasi langsung yang dilakukan terhadap para tenaga kerja dibagian produksi dan instalasi yang terdiri dari unit -unit berdasarkan pengolahan data maka diperoleh hasil sebagai berikut :

Berdasarkan Tabel 1 dapat dilihat bahwa hasil hubungan antara pelatihan dengan kejadian kecelakaan kerja dimana responden yang tidak mendapatkan pelatihan yang dikategorikan mengalami kecelakaan kerja sebanyak 44 (68\%) dan yang tidak mengalami kecelakaan kerja sebanyak $21(32 \%)$ sedangkan responden yang mendapatkan pelatihan dan dikategorikan mengalami kecelakaan kerja sebanyak 30 (73\%) dan yang tidak mengalami kecelakaan kerja sebanyak 11 (27\%).

Berdasarkan Tabel 2 dapat dilihat bahwa hasil hubungan antara pemeriksaan kesehatan dengan kejadian kecelakaan kerja dimana responden yang tidak pernah melakukan pemeriksaan kesehatan dikategorikan mengalami kecelakaan kerja sebanyak 54 (81\%) dan yang tidak mengalami kecelakaan kerja sebanyak 13 (19\%) sedangkan responden yang pernah melakukan pemeriksaan kesehatan dan dikategorikan mengalami kecelakaan kerja sebanyak $20(51 \%)$ dan yang tidak mengalami kecelakaan kerja sebanyak 19 (49\%).

Berdasarkan Tabel 3 dapat dilihat bahwa hasil hubungan antara pemeriksaan kesehatan dengan kejadian kecelakaan kerja dimana responden yang pengetahuannya rendah dikategorikan mengalami kecelakaan kerja sebanyak $39(62 \%)$ dan yang tidak mengalami kecelakaan kerja sebanyak $24(38 \%)$ sedangkan responden yang tinggi pengetahuannya dan dikategorikan mengalami kecelakaan kerja sebanyak $35(81 \%)$ dan yang tidak mengalami kecelakaan kerja sebanyak 8 (19\%).

Berdasarkan Tabel 4 dapat dilihat bahwa hasil hubungan antara pemeriksaan kesehatan dengan kejadian kecelakaan kerja dimana responden yang tidak menggunakan dikategorikan mengalami kecelakaan kerja sebanyak $63(75 \%)$ dan yang tidak mengalami kecelakaan kerja sebanyak 21 (25\%) sedangkan responden yang menggunakan dan dikategorikan mengalami kecelakaan kerja sebanyak $11(50 \%)$ dan yang tidak mengalami kecelakaan kerja sebanyak 11 (50\%).

Tabel 1

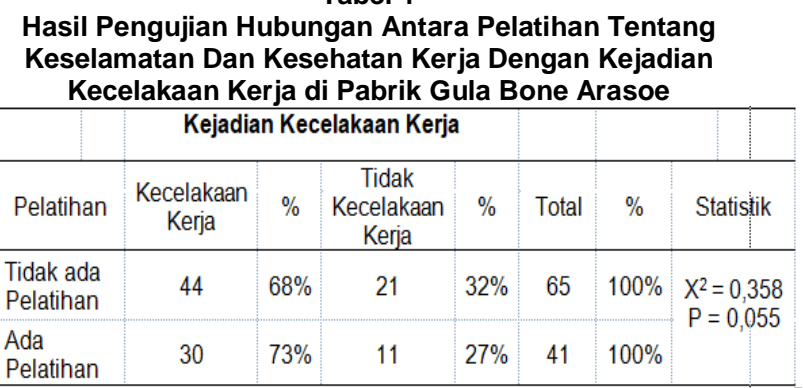

Sumber: Data Primer, 2019 
Jurnal Sulolipu : Media Komunikasi Sivitas Akademika dan Masyarakat

Vol. 19 No.2 2019

e-issn : 2622-6960, p-issn : 0854-624X

Tabel 2.5

Hasil Pengujian Hubungan Antara Pemeriksaan Kesehatan Dengan Kejadian Kecelakaan Kerja Di Pabrik Gula Bone Arasoe

\begin{tabular}{|c|c|c|c|c|c|c|c|}
\hline & \multicolumn{4}{|c|}{ Kejadian Kecelakaan Kerja } & & & \\
\hline $\begin{array}{l}\text { Pemeriksaan } \\
\text { kesehatan }\end{array}$ & $\begin{array}{l}\text { Kecelakaan } \\
\text { Kerja }\end{array}$ & $\%$ & $\begin{array}{l}\text { Tidak } \\
\text { Kecelakaan } \\
\text { Kerja }\end{array}$ & $\%$ & Total & $\%$ & Statistik \\
\hline Tidak pernah & 54 & $81 \%$ & 13 & $19 \%$ & 67 & $100 \%$ & $\begin{array}{l}X^{2}=10,052 \\
P=0,002\end{array}$ \\
\hline Pernah & 20 & $51 \%$ & 19 & $49 \%$ & 39 & $100 \%$ & \\
\hline
\end{tabular}

Tabel 3

Hasil Pengujian Hubungan Antara Pengetahuan Dengan Kejadian Kecelakaan Kerja Di Pabrik Gula Bone Arasoe

\begin{tabular}{|c|c|c|c|c|c|c|c|}
\hline & \multicolumn{4}{|c|}{ Kejadian Kecelakaan Kerja } & \multirow[b]{2}{*}{ Total } & \multirow[b]{2}{*}{$\%$} & \multirow[b]{2}{*}{ Statistik } \\
\hline Pengetahuan & $\begin{array}{c}\text { Kecelakaan } \\
\text { Kerja }\end{array}$ & $\%$ & \begin{tabular}{|c|} 
Tidak \\
Kecelakaan \\
Kerja
\end{tabular} & $\%$ & & & \\
\hline Rendah & 39 & $62 \%$ & 24 & $38 \%$ & 63 & $100 \%$ & \multirow[t]{2}{*}{$\begin{array}{l}X^{2}=4,607 \\
P=0,032\end{array}$} \\
\hline Tinggi & 35 & $81 \%$ & 8 & $19 \%$ & 43 & $100 \%$ & \\
\hline
\end{tabular}

Tabel 4

Hasil pengujian Hubungan antara Alat Pelindung Diri dengan kejadian kecelakaan kerja di Pabrik Gula Bone Arasoe

\begin{tabular}{|c|c|c|c|c|c|c|c|}
\hline & \multicolumn{4}{|c|}{ Kejadian Kecelakaan Kerja } & & & \\
\hline $\begin{array}{c}\text { Alat } \\
\text { Pelindung Diri }\end{array}$ & $\begin{array}{c}\text { Kecelakaan } \\
\text { Kerja }\end{array}$ & $\%$ & $\begin{array}{c}\text { Tidak } \\
\text { Kecelakaan } \\
\text { Kerja }\end{array}$ & $\%$ & Total & $\%$ & Statistik \\
\hline $\begin{array}{l}\text { Tidak } \\
\text { menggunakan }\end{array}$ & 63 & $75 \%$ & 21 & $25 \%$ & 84 & $100 \%$ & \multirow{2}{*}{$\begin{array}{l}X^{2}=5,170 \\
P=0,023\end{array}$} \\
\hline Menggunakan & 11 & $50 \%$ & 11 & $50 \%$ & 22 & $100 \%$ & \\
\hline
\end{tabular}

Sumber: Data Primer, 2019

\section{PEMBAHASAN}

Hubungan Antara Pelatihan Dengan Kejadian Kecelakaan

Berdasarkan hasil penelitian

menunjukkan bahwa tidak ada hubungan yang signifikan antara pelatihan dengan kejadian kecelakaan kerja di Pabrik Gula Bone Arasoe. $\mathrm{Hal}$ ini didasarkan pada hasil uji chi square yang diperoleh adalah $p$ value 0,055 ( $p$ value $>0,05$ ), maka $\mathrm{Ha}$ di tolak dan nilai Ho diterima.

Hal ini sejalan dengan penelitian Swaputri Eka (2010) yang mengatakan bahwa tidak ada hubungan antara pelatihan dengan kejadian kecelakaan kerja. Hasil penelitian ini menjelaskan bahwa sebagian besar pekerja yang ada di Pabrik Gula Bone Arasoe mendapatkan pelatihan, dan masih ada pekerja yang belum mendapatkan pelatihan. Hal ini dikarenakan pelatihan hanya diberikan kepada pekerja laki-laki, itupun hanya diambil perwakilan tiap bagian saja. Hal ini berkaitan erat antara pekerja dan perusahaan karena dapat merugikan kedua belah pihak jika tidak terlaksanakan.

Timbulnya kecelakaan kerja biasanya sebagai akibat atas kelalaian tenaga kerja atau perusahaan. Adapun kerusakan-kerusakan yang timbul, misalnya kerusakan mesin atau kerusakan produk, sering tidak diharapkan perusahaan maupun tenaga kerja. Namun tidak mudah menghindari kemungkinan timbulnya risiko kecelakaan dan kerusakan. Apabila sering timbul hal tersebut, tindakan yang paling tepat dan harus dilakukakan manajemen tenaga kerja adalah melakukan pelatihan. Penyelenggaraan pelatihan dimaksudkan agar pemeliharaan terhadap alat-alat kerja dapat ditingkatkan. Salah satu tujuan yang ingin dicapai adalah mengurangi timbulnya kecelakaan kerja, kerusakan, dan peningkatan pemeliharaan terhadap alat-alat kerja.

Pelatihan atau training K3 pada pekerja memainkan peranan penting dalam peningkatan kondisi kerja atau lingkungan kerja. Secara subtansial, upaya meningkatkan K3 ditempat kerja sering mengalami hambatan karena kurangnya kesadaran dari elemen yang terlibat. Untuk mengatasi hal itu, maka pelatihan K3 bagi pekerja penting sekali dapat memfasilitasi para karyawan dalam mendiagnosis masalah yang mungkin dihadapi dalam pekerjaan dan mungkin dihadapi dalam pekerjaan dan sekaligus membantu mereka mencari solusi tebaik untuk mengatasinya. Keuntungan pelatihan bagi pekerja baru adalah dapat ditanamkan kebiasaan dan tingkah laku yang aman dalam bekerja. Kebiasaan ini akan terbawa seterusnya sehingga dapat mendukung upaya pencegahan kecelakaan ditempat kerja. Sedangkan bagi pekerja lama yang berganti tugas atau menangani jenis pekerjaan baru, bisa dimanfaatkan untuk mengenal kebiasaan dan perilaku yang tidak aman yang kadang tidak disadarinya. Dengan demikian perilaku yang tidak aman ini bisa dihilangkan dan diganti dengan kebiasaan dan perilaku yang aman.

Tujuan dan sasaran sistem manajemen Keselamatan dan Kesehatan Kerja adalah menciptakan sistem keselamatan dan kesehatan kerja ditempat kerja dengan melibatkan unsur manajemen, tenaga kerja, kondisi dan lingkungan kerja yang terintegrasi dalam rangka mencegah dan mengurangi kecelakaan dan penyakit akibat kerja serta terciptanya tempat kerja yang aman, efisien dan produktif (Suwardi dkk, 2018). 

Hubungan Antara Pemeriksaan Kesehatan
Dengan Kejadian Kecelakaan Kerja Berdasarkan hasil penelitian menunjukkan bahwa ada hubungan yang signifikan antara pemeriksaan kesehatan dengan kejadian kecelakaan kerja. Hal ini didasarkan pada hasil uji chi square yang diperoleh adalah $p$ value 0,002 ( $p$ value $<0,05$ ) maka $\mathrm{H} 0$ ditolak dan Ha diterima.

Pemeriksaan kesehatan di pabrik Gula Bone Arasoe dilaksanakan dua kali dalam setahun. Dan dari hasil observasi didapatkan bahwa pemeriksaan kesehatan secara berkala tidak dilaksanakan. Hal tersebut dikarenakan bahwa tidak ada lagi perhatian mengenai pemeriksaan kesehatan secara berkala terhadap pekerja, klinik kesehatan yang ada di pabrik juga tidak berjalan secara maksimal. Maka hal tersebut dapat mengakibatkan timbulnya kecelakaan kerja pada pekerja. Pemeriksaan kesehatan sangat penting dilaksanakan pada setiap perusahaan, karena hal tersebut dapat mempengaruhi aktivitas pekerja.

\section{Hubungan Antara Pengetahuan Dengan Kejadian Kecelakaan Kerja} Berdasarkan hasil penelitian menunjukkan bahwa ada hubungan yang signifikan antara pengetahuan dengan kejadian kecelakaan kerja di Pabrik Gula Bone Arasoe. $\mathrm{Hal}$ ini didasarkan pada hasil uji chi square yang diperoleh adalah $p$ value 0,032 ( $p$ value $<0,05$ ) maka $\mathrm{H} 0$ ditolak dan Ha diterima.

Hasil penelitian dapat dilihat bahwa responden yang menjawab pengetahuan rendah lebih banyak dari pada responden yang menjawab pengetahuan tinggi. Selain itu berdasarkan hasil penelitian, responden yang menjawab pengetahuan rendah lebih banyak mengalami kecelakaan kerja dari pada responden yang menjawab pengetahuan tinggi.

$\mathrm{Hal}$ ini sejalan dengan penelitian yang dilakukan oleh (Rahayu, 2015) tentang hubungan antara pengetahuan karyawan terhadap kecelakaan kerja menunjukkan hasil uji variabel pengetahuan statistik didapat nilai $p$ value $<0.001$ sehingga dapat disimpulkan terdapat hubungan yang bermakna antara pengetahuan dengan kecelakaan kerja. Dari uji statistik juga didapatkan nilai Odd Ratio $=9,133$ $(95 \% \mathrm{Cl}=3,143-26,539)$ artinya responden yang mempunyai pengetahuan rendah memiliki resiko 9,133 kali tidak menerapkan manajemen budaya K3 dibandingkan responden yang mempunyai pengetahuan baik. Hasil penelitian lebih dari $50 \%$ responden yang berpengetahuan baik menerapkan budaya K3 dengan baik jadi pengetahuan responden sangat mempengaruhi penerapan budaya K3. Dapat diinterpretasikan bahwa semakin tinggi tingkat pengetahuan responden maka semakin baik pula penerapan budaya K3, dan pengetahuan juga dapat dipengaruhi oleh pengalaman yang diperoleh dari pengalaman sendiri maupun orang lain. Pengalaman yang diperoleh dapat memperluas pengetahuan seseorang. Pekerja yang memiliki pengetahuan tinggi akan mampu membedakan dan mengetahui bahaya disekitarnya serta dapat melakukan pekerjaan sesuai dengan prosedur yang ada karena mereka sadar akan risiko yang diterima, sehingga kecelakaan kerja dapat dihindari. Pekerja yang memiliki pengetahuan tinggi akan berusaha menghindari kecelakaan ringan karena mereka sadar bahwa kecelakaan ringan akan menyebabkan kecelakaan kerja yang lebih parah. Jika pekerja memiliki pengetahuan yang baik maka mereka akan bertindak positif dan berusaha untuk menghindari kecelakaan kerja (Utommi, 2017).

Sebaliknya pekerja yang memiliki pengetahuan rendah akan cenderung mengabaikan bahaya disekitarnya dan tidak melakukan pekerjaan sesuai prosedur karena ketidaktahuan akan risiko yang akan diterima. Pekerja yang memiliki pengetahuan keselamatan dan kesehatan kerja rendah akan cenderung bekerja terburu-buru dan hanya ingin menyelesaikan pekerjaan dengan cepat guna menghemat waktu dan waktu istirahat menjadi lebih cepat. Hal ini dikarenakan karena ketidaktahuan dan ketidaksadaran pekerja akan pentingnya prosedur dan peraturan dalam bekerja guna melindungi pekerja itu sendiri. Oleh karena itu pengetahuan pekerja yang rendah akan keselamatan dan kesehatan kerja dapat menimbulkan kecelakaan kerja di Pabrik Gula Bone Arasoe.

Dari hasil pengamatan dan observasi yang dilakukan peneliti di Pabrik Gula Bone Arasoe, kecelakaan kerja disebabkan karena kurangnya pengetahuan pekerja akan resiko potensi bahaya yang memungkinkan terjadi. Kecelakaan kerja juga bisa terjadi karena kurangnya sosialisasi dan pengetahuan K3 yang berikan oleh perusahaan kepada pekerjanya, sehingga pekerja memiliki pengetahuan $\mathrm{K} 3$ yang buruk. Cara pengembangan sikap/pengetahuan/keahlian yang diperlukan oleh seseorang untuk melaksanakan tugas atau pekerjaannya secara memadai adalah dengan melakukan pelatihan yang rutin. Perusahaan telah memberikan pengetahuan K3 kepada pekerja. Akan tetapi sebaiknya perusahaan memberikan test terkait materi pengetahuan K3 sebelum dan sesudah dilakukan pengetahuan K3 kepada pekerja. Hal ini dimaksudkan agar perusahaan dapat mengukur apakah 
pengetahuan K3 yang dilakukan efektif atau tidak.

Namun masih ada beberapa pekerja yang tidak sadar betapa pentingnya keselamatan dalam bekerja, masih ada pekerja yang tidak memikirkan akibat resiko yang timbul jika tidak mematuhi peraturan-peraturan yang ada di perusahaan yang berkaitan dengan keselamatan itu sendiri. Pekerja sebaiknya memiliki pengetahuan keselamatan dan kesehatan kerja yang cukup agar dapat mengidentifikasi bahayabahaya yang ada di tempat kerja yang dapat mengancam dirinya, tujuan dari identifikasi bahaya yang dimaksudkan yaitu penilaian risiko dengan memperkirakan tingkat keparahan yang akan timbul jika pekerja mendapatkan kecelakaan kerja, ketika risiko telah dianalisis dan dinilai pekerja dapat membuat keputusan tentang tindakan pencegahan, dengan demikian pekerja dapat menghindari terjadinya kecelakaan kerja ataupun dapat mengurangi tingkat keparahan yang akan timbul.

Peningkatan pengetahuan tidak selalu menyebabkan perubahan perilaku, akan tetapi pengetahuan sangat penting diberikan sebelum individu melakukan suatu tindakan. Karna tindakan akan sesuai dengan pengetahuan apabila individu menerima isyarat yang cukup kuat untuk memotivasi dirinya untuk bertindak sesuai dengan pengetahuannya.

\section{Hubungan Antara Alat Pelindung Diri Dengan Kejadian Kecelakaan Kerja}

Berdasarkan menunjukkan bahwa ada hubungan yang signifikan antara Alat Pelindung Diri dengan kejadian kecelakaan kerja di Pabrik Gula Bone Arasoe. Hal ini didasarkan pada hasil uji chi square yang diperoleh adalah $p$ value 0,023 ( $p$ value $<0,05$ ) maka $\mathrm{HO}$ ditolak dan Ha diterima.

Penelitian ini sejalan dengan penelitian yang dilakukan oleh A Syamsinar (2013) dimana ada hubungan antara penggunaan Alat Pelindung Diri dan ketersediaan Alat Pelindung Diri secara lengkap dengan kejadian kecelakaan kerja pada pekerja di PT. Perkebunan Nusantara Pabrik Gula Bone bagian produksi pada tahun 2013.

Hasil penelitian yang dilakukan oleh Sulhinayatillah (2017) di PT PP. London Sumatra Indonesia Tbk,Palangisang Crumb Rubber Factory, juga sejalan dimana ada hubungan dengan penggunaan Alat Pelindung Diri dengan kejadian kecelakaan kerja. di ketahui bahwa dari 54 responden yang tidak lengkap menggunakan APD sesuai dengan yang dibutuhkan di tempat kerjanya ada sebanyak 47 responden $(54.7 \%)$ yang pernah mengalami kecelakaan kerja dan dari 32 responden yang lengkap menggunakan
APD pada saat bekerja ada sebanyak 11 responden (12.8\%) yang pernah mengalami kecelakaan kerja sebagian besar pekerja menganggap bahwa tidak perlu menggunakan Alat Pelindung Diri pada saat bekerja karena faktor ketidaknyamanan saat bekerja sehingga dianggap mengganggu produktivitas pekerjaan, disamping itu, tidak tersedianya Alat Pelindung Diri di tempat kerja menyebabkan tidak terbiasanya pekerja menggunakan Alat Pelindung Diri saat bekerja.

Kurangnya ketersediaan Alat Pelindung Diri di Pabrik Gula Bone Arasoe merupakan salah satu faktor adanya kecelakaan kerja. Dan masih banyak pekerja yang tidak menggunakan alat pelindung diri pada waktu bekerja. Hal tersebut dikarenakan bahwa pekerja merasa tidak nyaman jika menggunakan alat pelindung diri pada saat bekerja. Dan tidak ada teguran/sanksi dari pihak pengawas apabila tidak menggunakan alat pelindung diri.

Tindakan responden yang kurang dalam penggunaan Alat Pelindung Diri dapat dipengaruhi oleh banyak faktor. Faktor internal (berupa respons) dan faktor ekstenal (berupa stimulus) sangat berpengaruh terhadap tindakan penggunaan Alat Pelindung Diri. Faktor internal merupakan faktor dari dalam diri seseorang dalam merespons stimulus dari lingkungannya. Faktor eksternal atau stimulus adalah faktor lingkungan, baik fisik maupun nonfisik dalam bentuk sosial, budaya, ekonomi dan politik (Irzal, 2016).

\section{KESIMPULAN}

Faktor-faktor yang berhubungan dengan kejadian kecelakaan kerja di Pabrik Gula Bone Arasoe yaitu pemeriksaan kesehatan secara berkala tidak terlaksana, pekerja yang pengetahuannya rendah sebanyak (62\%), dan tidak menggunakan Alat Pelindung Diri sebanyak $(75 \%)$, serta kurangnya ketersediaan Alat Pelindung Diri secara lengkap di Pabrik Gula Bone Arasoe.

\section{SARAN}

Sebaiknya pihak perusahaan dapat menyediakan alat pelindung diri secara lengkap seperti helm, sepatu safety, sarung tangan, kacamata pengaman, masker, dan penutup telinga. Dan sesuai bidang pekerjaan masingmasing, serta adanya teguran pada pekerja yang tidak menggunakan Alat Pelindung Diri. Melakukan pemeriksaan kesehatan secara berkala pada karyawan.

Melakukan pengawasan sebelum masuk dalam area produksi dan pihak perusahaan sebaiknya melakukan pelaporan setiap 1 kali seminggu. Dan memberikan pelatihan berupa 
Jurnal Sulolipu : Media Komunikasi Sivitas Akademika dan Masyarakat

Vol. 19 No.2 2019

e-issn : 2622-6960, p-issn : 0854-624X

instruksi praktis bagi para pekerja yang tidak membiasakan diri menggunakan Alat Pelindung mengikuti pelatihan. tenaga pekerja dapat Diri pada waktu bekerja.

\section{DAFTAR PUSTAKA}

A Syamsinar Asmi Hamza K, 2013. Faktor Yang Berhubungan Dengan Penggunaan Alat Pelindung Diri (APD) Pada Karyawan Unit Produksi PTPN X (PERSERO) Pabrik Gula Arasoe Bone. Dosen Akademi Keperawatan Sandi Karsa Makassar.(Online). http://artikel.dikti.go.id/pelatihan/index.php/pojs03/issue/download/343/14. (Diakses Pada Tanggal 10 Januari 2019).

Fitria Ciptaningsih, Dkk, 2014. Evaluasi Sistem Manajemen Keselamatan Dan Kesehatan Kerja (SMK3) di PT Industri Baja. Fakultas Kesehatan Masyarakat. Universitas Diponegoro. (Online). https://ejournal3.undip.ac.id/index.php/ikm/article/viewFile/6410/6188. (Diakses Pada Tanggal 19 Desember 2018).

ILO (International Labour Organization), 2013. Keselamatan Dan Kesehatan Kerja Sarana Untuk Produktivitas. Jakarta : International Labour Offical.

Ismi Elya Wirdati, Dkk, 2015. Analisis Faktor-Faktor Yang Mempengaruhi Kecelakaan Kerja Pada Pekerja Maintenance Elektrikal Dalam Menerapkan Work Permit Di PT. X Semarang. Fakultas Kesehatan Masyarakat. Universitas Diponegoro. (Online). https://ejournal3.undip.ac.id/index.php/ikm/article/view/12312. (Diakses Pada Tanggal 10 Januari 2019).

Luthfil Hadi Anshari, Dkk, 2016. Faktor-Faktor Yang Berhubungan Dengan Kecelakaan Kerja Pada Karyawan PT Kunanggo Jantan Kota Padang Tahun 2016. Fakultas Kesehatan Masyarakat. Universitas Andalas. (Online). https://docplayer.info/47830138-Faktor-faktoryang-berhubungan-dengan-kecelakaan-keria-pada-karyawan-pt-kunanggo-jantan-kotapadang-tahun-2016.html. (Diakses Pada Tanggal 12 Januari 2019).

Pemerintah Kota Makassar. 2018. Rencana Kerja Dinas Tenaga Kerja Kota Makassar. pdf. https://disnaker. makassar.go.id/2017/11/9. (Diakses Pada Tanggal 14 Desember 2018).

Republik Indonesia, 1998. Peraturan Menteri Tenaga Kerja Nomor: 03/MEN/98. Tentang Tata Cara Pelaporan Dan Pemeriksaan Kecelakaan Kerja.https://jdih.kemnaker.go.id.1998-2-4. (Diakses Pada Tanggal 24 Desember 2018).

Rahayu, Endang. 2015. Hubungan Antara Pengetahuan, Sikap, dan Perilaku Karyawan dengan Penerapan Manajemen Budaya Keselamatan dan Kesehatan Kerja. Jurnal Kesehatan Komunitas. Volume 2. Nomor 6. Halaman 289-293. (Online) https://www.researchgate.net/publication/318196026 Hubungan Antara Pengetahuan Si kap dan Perilaku Karyawan dengan Penerapan Manajemen Budaya Keselamatan da n Kesehatan Keria. (Diakses Pada Tanggal 25 Mei 2019).

Rini Riestiany, Dkk. 2010. Analisis Pengaruh Efektivitas Penerapan Sistem Manajemen Keselamatan Dan Kesehatan Kerja (SMK3)Terhadap Produktivitas Kerja Karyawan (Study Kasus Plant 11 PT Indocement Tunggal Prakarsa, Tbk Citeureup). Departemen Manajemen, Fakultas Ekonomi Dan Manajemen, IPB.(Online)http://jurnal.jpb.ac.id/index.php/imo/article/download/14152/10546. (Diakses Pada Tanggal 13 Desember 2018).

Suwardi, Dkk. 2018. Keselamatan dan Kesehatan Kerja dan Lingkungan Hidup. Edisi ke-1. Jilid 1. Yogyakarta : Gava media.

Sugiyono, 2013. Metode Penelitian Pendidikan Kuantitatif, Kualitatif, Dan R\&D. Bandung : Alfabeta Bandung.

Sulhinayatillah, 2017. Faktor-Faktor Yang Berhubungan Dengan Kejadian Kecelakaan Kerja Pada Karyawan Bagian Produksi di PT. PP London Sumatra Indonesia Tbk, Palangisang Crumb Rubber Factory, Bulukumba Sulawesi Selatan 2017. Fakultas Kedokteran Dan 
Jurnal Sulolipu : Media Komunikasi Sivitas Akademika dan Masyarakat

Vol. 19 No.2 2019

e-issn : 2622-6960, p-issn : 0854-624X

IImu Kesehatan. Universitas Islam Negeri Alauddin Makassar.(Online).https://repositori.uin-alauddin.ac.id.Pdf. (Diakses Pada Tanggal 20 Januari 2019).

Swaputri Eka, 2010. Analisis Penyebab Kecelakaan Kerja. Jurusan IImu Kesehatan Masyarakat Fakultas IImu Keolahragaan. Universitas NegeriSemarang.(Online).https://www.neliti.com/publications/25346/analisis-penyebabkecelakaan-kerja. (Diakses Pada Tanggal 12 Januari 2019).

Utommi, S. 2017. Gambaran tingkat kepatuhan pekerja dalam mengikuti prosedur operasi pada pekerja operator dump truck PT. Kaltim Primacoal. Jurnal Kesehatan Masyarakat. Volume 2. Nomor 3. ISSN 2163-3245. 